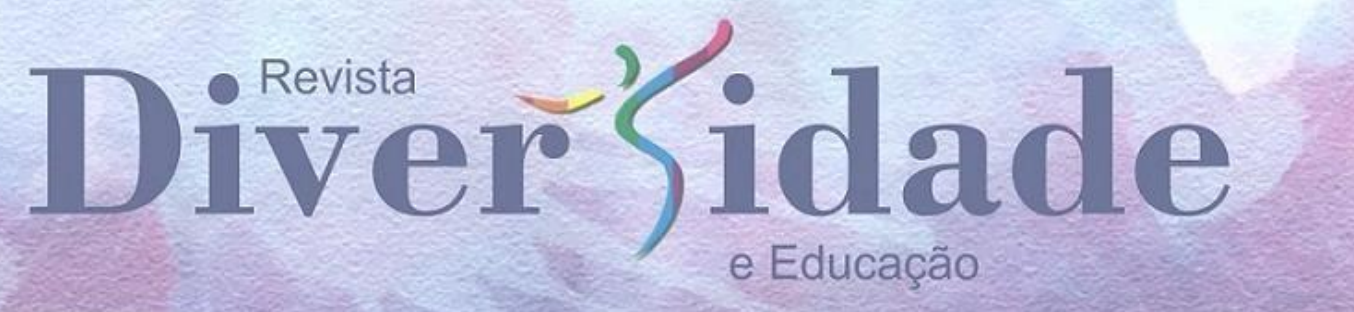

\title{
MEMÓRIAS, HISTÓRIAS DE VIDAS E TRABALHO ARTESANAL DE MULHERES QUILOMBOLAS DE SÃO LOURENÇO DO SUL/RS
}

\section{MEMORIAS, HISTORIAS DE VIDA Y TRABAJO ARTESANAL DE MUJERES QUILOMBOLAS EN SÃO LOURENÇO DO SUL / RS}

\section{MEMORIES, LIFE STORIES AND ARTISANAL WORK OF QUILOMBOLAS WOMEN IN SÃO LOURENÇO DO SUL / RS}

\author{
Graziela Rinaldi da Rosa ${ }^{1}$ \\ Universidade federal de Rio Grande/FURG \\ MichaellaSant' Anna ${ }^{2}$ \\ Universidade Federal de Rio Grande/FURG \\ Adriana da Silva Ferreira ${ }^{3}$ \\ Universidade federal de Rio Grande/FURG
}

\section{RESUMO}

A pesquisa apresentada nesse artigo, teve como como objetivo principal conhecer as mulheres que vivem nos cinco quilombos de São Lourenço do Sul/RS, através de

\footnotetext{
${ }^{1}$ Professora adjunta da Universidade Federal do Rio Grande. Atuou como professora de Filosofia na Educação básica. Atua na formação de professores/as. É integrante do Núcleo de Pesquisa Sexualidade e Escola (FURG) e do Núcleo de Estudos Feministas e de Gênero/UFPEL. É responsável pela pesquisa "Mulheres Quilombolas: identidades, vivências e memórias" (2017-2019), que teve apoio da FAPERGS e do CNPq. Email: grazirinaldi@gmail.com

${ }^{2}$ Graduanda no curso de Licenciatura em Educação do Campo- Ênfase em ciência da natureza e ciências agrárias/FURG; Bolsista da pesquisa Mulheres quilombolas de São Lourenço do Sul/RS; Integrante do Movimento de Consciência negra de São Lourenço do Sul/RS. Email: michaellasantanna@gmail.com

${ }^{3}$ Quilombola do Quilombo da Coxilha Negra; Graduada no curso de Educação do Campo- ênfase em Ciências da Natureza e Ciências Agrárias/FURG; Bonequeira da Pesquisa "Mulheres quilombolas de São Lourenço do Sul/RS”. Email: Adri.silvaf77@gmail.com
} 
encontros em forma de rodas de diálogos e oficinas de bonecas negras. Além desses quilombos, também foi realizada uma entrevista com uma liderança do movimento de consciência negra, que está contribuindo para a reconstrução e reconhecimento de outro quilombo. As mulheres compartilharam suas histórias de vidas, dificuldades e preconceitos que sofrem enquanto negras e quilombolas, e denunciaram os problemas que enfrentam, bem como os problemas de suas comunidades. Durante os encontros falou-se, entre outros temas, sobre o que é ser mulher quilombola, educação, trabalho das mulheres nos Quilombos, violência contra as mulheres, do trabalho artesanal como forma de renda, de representatividade.

PALAVRAS CHAVE: Comunidades quilombolas. Mulheres negras. Narrativas de vida. Auto reconhecimento.

\title{
RESUMEN
}

La investigación presentada en este artículo tuvo como objetivo principal conocer a lasmujeres que vivenenlos cinco quilombos de São Lourenço do Sul / RS, a través de reunionesen forma de ruedas de diálogo y talleres de muñecas negras. Además de estos quilombos, también se realizó una entrevista conun líder delmovimiento de conciencia negra, que está contribuyendo a lareconstrucción y elreconocimiento de otro quilombo. Lasmujerescompartieron sus historias de las vidas, lasdificultades y losprejuicios que sufren como negras y quilombolas, y denunciaronlos problemas que enfrentan, así como los problemas de sus comunidades. Entre otros temas, lasreunioneshablaron sobre ser una mujer quilombola, educación, trabajo de mujeresen Quilombos, violencia contra lasmujeres, trabajo artesanal como una forma de ingresos y representatividad.

PALABRAS CLAVE: comunidades quilombolas. Mujeres negras. Narrativas de la vida. Auto reconocimiento

\begin{abstract}
The research presented in this article had as its main objective to get to know the women who live in the five quilombos of São Lourenço do Sul / RS, through meetings in the form of dialogue wheels and workshops of black dolls. In addition to these quilombos, an interview was also conducted with a leader of the black conscience movement, which is contributing to the reconstruction and recognition of another quilombo. The women shared their stories of the lives, hardships and prejudices they suffer as blacks and quilombolas, and denounced the problems they face as well as the problems of their communities. Among other topics, the meetings talked about being a quilombola woman, education, women's work in Quilombos, violence against two men, craftwork as a form of income, and representativeness.
\end{abstract}

KEYWORDS: Quilombola communities. Black women. Narratives of life. Self Recognition.

\section{Acreditando em sonhos: uma introdução}


O que aconteceu com os quilombos depois de 1888 com o fimda escravidão? Com a sua extinção não havia mais escravos e, portanto, fugitivos. Mas os quilombos e mocambos continuaram a se reproduzir mesmo com o fim da escravidão. Eles nunca desapareceram, porém não os encontramos mais na documentação de polícia e nas denúncias dos jornais. Os vários quilombos - que já eram verdadeiras microcomunidades camponesas - continuaram se reproduzindo, migrando, desaparecendo, emergindo e se dissolvendo no emaranhado das formas camponesas do Brasil de Norte a Sul (GOMES, 2015, p.120).

Ainda se escuta falar pouco dos quilombos do Sul do Brasil. Terra de colonização alemã, em que tentam esquecer e silenciar os/as remanescentes dos quilombos. É incrível como se tenta negar uma história, mesmo quando almoçam nas antigas senzalas. Negam a existência dos quilombos, outrora já reconhecidos.

Ao todo temos cinco quilombos no município: (1) Quilombo da Coxilha Negra, (2) Quilombo Rincão das Almas, (3) Quilombo da Picada, (4) Quilombo do Torrão, (5) Quilombo Monjolo, também denominado Serrinha até o ano de 2005, situado no subdistrito deCampos Quevedos.

Participaram da pesquisa, cerca de 40 mulheres, e 10 meninas, dessas mulheres, quatorze vivem no Quilombo da Coxilha Negra; Quilombo do Torrão (7 participantes); Quilombo Rincão das Almas (12 participantes); Quilombo da Picada (2 participantes); Quilombo Monjolo (4 participantes); Quilombo das Nascentes (uma liderança do Movimento de Consciência Negra).

Chama-se "Quilombo da Picada", porque os/as antigos/as moradores/as escravos, que se refugiavam ali, faziam uma trilha dentro do mato, para não serem encontrados por seus antigos "donos". Essas trilhas eram chamadas de Picada. Nesse quilombo tem uma parte denominada "Figueira Branca", devido a presença de uma figueira branca.

Sabe-se que "a Vila do Torrão recebe este nome porque as casas, há anos, eram feitas deste material (torrão de terra). (RUBERT, 2005, p. 61). Ao realizar um levantamento socioantropológico preliminar das Comunidades negras rurais do Rio Grande do Sul/RS, Rosane Rubert (2005), nos apresenta algumas características dessas comunidades, e destaca os laços de parentesco que existe em algumas comunidades, e traz relatos históricos importantes para a história do povo negro e para as comunidades quilombolas da na região: 
M.L.S (66 anos), residiu no Faxinal até a adolescência, tempo suficiente, no entanto, para assimilar de seu avô (João Ferreira) e avó (Maria Custódia Ferreira) maternos a memória de uma fuga de escravos que resultou na formação de várias comunidades quilombolas de São Lourenço: 'É. Eu sei que fugiu um lote do município de Canguçu, cá onde tinha os escravos. A minha vó tinha um buraco assim [na orelha] onde eles botavam o cadeado, que pecado! (...) Ah, eu acho que fugiram uns doze, treze, mais ou menos, fugiram". Ao chegarem a uma altura do caminho, durante a fuga, este grupo de escravos teria se subdividido de forma a dificultar o resgate por parte das forças repressivas, formando vários núcleos de moradia. Outras duas comunidades negras localizadas próximas à Vila Torrão (Picada e Serrinha [atual Monjolo]) teriam surgido deste mesmo processo de aquilombamento. Vários moradores da Vila Torrão fazem referência a sua origem citando o município de Canguçu. (RUBERT, 2005, p. 61).

Mesmo com a presença dessas comunidades, São Lourenço do Sul é uma cidade conhecida apenas como de colonização pomerana e alemã localiza-se no Sul do Estado do Rio Grande do Sul, distante cerca de $200 \mathrm{~km}$ da capital Porto Alegre, a principal fonte de economia de seus 44.935 habitantes (dados do IBGE, de 2014) é a agricultura e o turismo. Ainda assim, neste cenário, somam-se à estatística quilombola, a presença dessas resistentes populações.

Além das quilombolas, temos a presença de indígenas, ribeirinhos/as, agricultores/as familiares, ciganos/as, quilombolas, agricultores/as familiares, benzedeiras, povos de terreiro, pecuaristas, pomeranos, grupos de pessoas envolvidos/as com a cadeia produtiva da pesca, como pescadores/pescadoras. Trata-se de uma rica diversidade humana e cultural, que ainda está invisibilizada e ocultada pelo patriarcado, o racismo, paternalismo, evangelização, o colonialismo e o que a filósofa Márcia Tiburi denominou de "coronelismo intelectual":

Podemos chamar de "coronelismo intelectual" a prática autoritária no campo do conhecimento. Este campo é extenso, ele começa na pesquisa científica universitária e se estende pela sociedade como um todo, dos meios de comunicação ao básico botequim onde ideias entram em jogo. Coronelismo intelectual é a postura da repetição à exaustão de ideias alheias. A reflexão só atrapalharia, por isso é evitada. Encarnação de prepotente eloquência, o paradoxo do coronelismo é alimentar uma ordem coletiva de silêncio em que o debate inexiste, o culto da verdade pronta ou da ignorância é a regra, bem como a apologia ao gesto de falar sem ter nada a dizer que culmina no discurso tão vazio quanto maldoso da fofoca, versão popular do eruditismo, ambos parte do consumismo da linguagem em voga [...] (TIBURI, 2016. p. 125). 
As lideranças do movimento negro local, lutam para que seja reconhecido que São Lourenço do Sul foi construído por mão de obra escravizada. Depois da abolição os/as negros/as, livres, sem emprego ou ganhando muito pouco foram formando comunidades e se fixando nas comunidades existentes na zona rural, em lugares distantes e de difícil acesso formando os quilombos.

Desde os anos 1980, se tem uma luta por este reconhecimento com a fundação do movimento de consciência negra de São Lourenço do Sul, mas conforme relatam algumas lideranças locais, com a chegada da Universidade Federal do Rio Grande/FURG, esta resistência ganhou mais força, porque além do curso de Licenciatura em Educação do campo, que tem estudantes de diferentes comunidades quilombolas, os/as estudantes quilombolas passaram a ter a oportunidade de trabalharem com pesquisa, ensino e extensão voltados para o fortalecimento de sua cultura, sua ancestralidade e de suas comunidades, em busca da superação dos problemas que ainda enfrentam, o tensionamento para implementação de políticas públicas locais, e também da qualidade de vida dessas pessoas. Além do Curso mencionado, temos também estudantes quilombolas entre os outros cursos que a Universidade oferece no município, como por exemplo o Curso de Gestão Ambiental, Gestão de Cooperativas e o de Agroecologia.

\begin{abstract}
Os números relativos a quantidade de comunidades de quilombo no Brasil são variáveis. Segundo dados do instituto nacional de colonização e reforma agrária (INCRA) e fundação palmares(FCP), na atualidade, foram expedido 154 títulos para comunidades negras rurais contemplando 127 territórios e 217 comunidades, somando um número total de 13.145 famílias e uma área de 1.007.827,8730 hectares. Em relação ao número de certidões de autodefinição conferida às comunidades quilombolas, estes perfazem um total de 2.408 certidões expedidas. (NUNES, 2016, p. 163)
\end{abstract}

São muitos os desafios do povo negro em São Lourenço do Sul. Um município que apesar de contar com cinco quilombos reconhecidos e ter um em fase de reconhecimento, ainda renega muito a existência, a legitimidade e a presença da história negra nos seus 135 anos de emancipação. A única cultura valorizada e dita como fundadora do município é a Pomerana ${ }^{4}$.

No entanto, como afirmou Bárbara Oliveira de Souza (2016, p. 22):

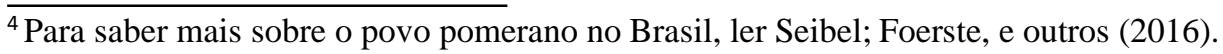


[...] os quilombolas abriram suas estradas, seus caminhos, e formaram suas comunidades, adaptando estratégias aos diversos cenários existentes, nas mais variadas regiões do Brasil. De predominância negra, destacam-se também as relações interétnicas na formação das comunidades quilombolas, tais como as estabelecidas entre indígenas e brancos.

Cabe destacar ainda sobre esse movimento de luta, e de resistências, que:

O movimento de luta pela garantia dos direitos dessas comunidades é histórico e político. Traz em seu íntimo uma dimensão secular de resistência, na qual homens e mulheres buscavam o quilombo como possibilidade de se manterem física, social e culturalmente em contraponto à lógica escravocrata (SOUZA, 2016, p. 19).

Assim, reconhecemos nosso lugar de fala. Uma autora branca, filha de operário, que trabalhou como doméstica, e hoje é professora Universitária de uma Universidade Federal, responsável por uma pesquisa, que se propôs a conhecer e dialogar com as mulheres que permanecem nos quilombos, (re) existindo e reinventando-se em seus territórios de povos tradicionais/originários, através de seus saberes, seus artesanatos, suas próprias histórias de vidas. Duas autoras que nasceram em quilombos. Mãe jovem, menina negra, criada por sua avó quilombola, que teve que buscar trabalho na cidade para criar suas filhas e netas. E por fim, a terceira autora, que segue vivendo e vivenciando todos os dias a realidade de ser mulher negra quilombola. Bonequeira e agricultora familiar, que se insere numa universidade pública e reforça a sua identidade e sentimento de pertença a essa comunidade.

Adriana da Silva Ferreira da comunidade quilombola da Coxilha Negra, ingressa no curso de educação do campo em 2014. Foi a primeira quilombola a cursar Licenciatura em Educação do Campo na Universidade Federal do Rio Grande/FURG. Artesã/bonequeira, agricultora familiar e mulher negra quilombola, se desafia em retornar para as salas de aulas e cursar uma graduação.

Ser mulher quilombola é um grande desafio, a gente tem que aprender a ser quilombola. A gente nasce mulher negra, mas quilombola a gente tem que aprender a ser. (Adriana da Silva Ferreira. Documentário mulheres quilombolas de São Lourenço do Sul/RS, 20195)

No mesmo ano de sua inserçãofoi possível que a estudante quilombola fosse em encontros, seminários e congressos ${ }^{6}$ que estudavam sobre "feminismo e mulheres de

\footnotetext{
${ }^{5}$ Para assistir o documentário, ver: https://www.youtube.com/watch?v=AH3HUliU5zk

${ }^{6}$ Como exemplo de alguns lugares por onde andamos em 2014 e 2015, início de nossa trajetória conjunta, podemos mencionar: II Seminário Internacional de Educação do Campo e Fórum Regional do Centro e
} 
povos tradicionais". Naquele momento (2014 e 2015) iniciamos nossas leituras a partir de epistemologias Feministas da América Latina. Conhecíamos pouco sobre os feminismos negros.

Por saber confeccionar bonecas negras ela conta sobre o seu sonho de ensinar as outras mulheres dos quilombos a fazê-las. Também relata como surgiu a ideia de fazer a primeira boneca negra, quando uma de suas sobrinhas lhe pediu, e a partir daí a quilombola acreditou que essa menina se sentisse representada e assim ela fez deixando sua sobrinha bem feliz e emocionada.

Foi então que uma educadora popular feminista, inserida como docente do Instituto de Educação, e professora de Filosofia e Educação Popular no Curso de Licenciatura em Educação do Campo acreditou no sonho desta quilombola.

Percebeu-se então a necessidade de fortalecer as identidades das mulheres quilombolas, especialmente as negras, que vivem nos quilombos, bem como de valorizar as memórias e histórias delas, e contribuir com o reconhecimento da história do povo negro no município.

Juntas (professora e estudante), construíram o projeto de pesquisa para e com as mulheres quilombolas do município. Ousou-se pensar que as narrativas de vida, fossem motivadas pelas rodas de conversas, enquanto as mulheres confeccionam bonecas negras. Foi construída uma entrevista semi-estruturada, que guiasse o roteiro, especialmente para a produção do documentário.

Assim, entendemos que todas as pessoas possuem lugares de fala, pois estamos falando de localização social. E a partir disso, é possível debater e refletir criticamente sobre os mais variados temas presentes na sociedade. O fundamental é que indivíduos pertencentes ao grupo social privilegiado em termos de locussocial, consigam enxergar hierarquias produzidas a partir desse lugar e como esse lugar impacta diretamente na constituição dos lugares de grupos subalternizados (RIBEIRO, 2017, p.86).

Sul do RS. 2014; II SIFEDOC-Seminário Internacional e Fórum de Educação do Campo. Identidades e Epistemologias do Campo: (Re) Leituras sobre Educação do Campo na Formação Docente. 2014. (Seminário); I Seminário Regional: Povos Tradicionais, Cultura Local e Emancipação. Educação e Diversidade. 2014. (Seminário); I Colóquio Diversidade na Universidade. 2014; VII Seminário Internacional Pensamento Crítico-Constitucionalismos, democracias e educação (2015); Seminário AMNB: Marcha das Mulheres Negras 2015-Região Sul. 2015; Marcha das Mulheres Negras (Brasília); IV Congresso Latino-Americano de Gênero e Religião (2015); I Seminário da Mulher do Campo e da Cidade de São Lourenço do Sul (2015); III Seminário Regional de Educação do Campo (2015); II Colóquio Mulheres, feminismo, artesanato e arte popular (2015); I ENCONTRO DE POVOS E COMUNIDADES TRADICIONAIS DO PAMPA (2015); Curso Saúde e Cidadania no Quilombo (2015). 
Aos poucos fomos aprendendo que pouco sabíamos sobre feminismos, e passamos a olhar mais para as mulheres negras escritoras, autoras, educadoras e militantes. Aprendemos que "[...] a concepção de mundo que interessa ao feminismo negro se utiliza de todos os sentidos" (AKOTIRENE, 2019, p. 24). Aprendemos na práxis as cores do feminismo negro. $\mathrm{E}$ aos poucos fomos entendendo que as mulheres negras, não querem que falem de si. Não querem ser representadas, especialmente por um "feminismo branco", ou por mulheres brancas. Querem e sonham ter o seu lugar de fala. Por isso falam das suas histórias de vidas, de suas ideias e teorias, do seu fazer artesanal, científico, doméstico, comunitário... apresentam seus conceitos, seus métodos, e concretizam seus sonhos!

\section{Sobre ser mulher negra e quilombola}

Pra mim ser quilombola é ser negra e que todo mundo se respeitem por cada cor que você tem, que não te julgue pela aparência que tem, que a gente tem...(Paloma Moura Fonseca, 2019, acervo da pesquisa)

São as histórias de vidas das mulheres que nos encantam. As experiências de vida das mulheres negras, suas lutas e protagonismos, bem como suas memórias. Para tanto, Marie-Christine Josso (2004) tem nos auxiliado. As narrativas e a história oral permitem explicitar a singularidade de cada mulher entrevistada, e participante das rodas de diálogos. Nesse sentido, as mulheres dos quilombos de São Lourenço do Sul foram provocadas a olhar para si próprias, e para suas histórias de vidas, encontrando no coletivo de mulheres suas semelhanças, aprendendo a caminhar com as outras.

Nesse sentido, sabemos que essa pesquisa conseguiu captar apenas uma parte das histórias de vidas, do que elas entendem sobre "ser mulher quilombola", e das memórias das mulheres dos quilombos de São Lourenço do Sul. O que nos motivou nesse momento, foi que imaginar que elas pudessem ter um momento para pensar sobre si mesmas, e na possibilidade de se auto organizarem através do artesanato (confecção de bonecas negras). E ainda, que a comunidade passasse a conhecer um pouco mais os quilombos do Sul, e as mulheres que ali vivem.

Durante os encontros, as mulheres demonstraram ter claro o papel que desenvolvem na comunidade, mas vimos que não são todas que compreendem o que é ser uma mulher quilombola. Em um dos encontros, uma jovem mãe, disse: 
O maior papel da mulher no quilombo é preservar as receitas. Essas coisas de casa, a educação dos filhos, brincadeiras, essas coisas que todas as mães passa pros filhos, mas que tem raízes quilombolas (Mariela Centeno, 2019, Acervo da pesquisa.)

O exercício de pensar sobre si, e suas histórias de vidas nos faz seguir acreditando nesse tipo de trabalho, estudo e pesquisa. Sabemos que uma pesquisa não dá conta da dimensão epistemológica da história das mulheres dos quilombos, de suas memórias e narrativas de vida, tampouco da totalidade dessa diversidade. No entanto, essa é apenas mais uma pesquisa, talvez, a primeira pesquisa-ação participante que se utiliza da confecção de bonecas negras, para desenvolver os encontros e ouvir as vozes das mulheres dos Quilombos.

As vozes, que atuam na recuperação da memória, vêm mostrar a interferência de muitos outros fatores no momento do relato. $\mathrm{O}$ primeiro é a seletividade da memória. A memória é seletiva e envolve, não apenas lembranças, mas também silêncios e esquecimentos (KENSKI, s/a, p. 109).

Trata de uma pesquisa que dá sequência a um conjunto de estudos, trabalhos e pesquisas que a primeira autora tem desenvolvido, primeiramente com mulheres professoras de filosofia (pesquisa de mestrado), com mulheres na história da educação (pesquisa de doutorado), e ainda mulheres nas fontes pedagógicas do pensamento Latinoamericano (trabalho de pós-doutoramento).

Hoje, inseridas em um curso de Licenciatura em Educação do Campo, as autoras se propõem a pensar sobre suas trajetórias e as de outras mulheres, fortalecendo suas histórias de vida, seus saberes, fazeres e o "ser mulher, nos diferentes espaços e territórios. Nesse sentido:

O que está em jogo neste conhecimento de si mesmo não é apenas compreender como nos formamos por meio de um conjunto de experiências, ao longo da nossa vida, mas sim, tomar consciência de que este reconhecimento de si mesmo como sujeito, mais ou menos ativo ou passivo segundo as circunstâncias, permite à pessoa, daí em diante, encarar o seu itinerário de vida, os seus investimentos e os seus objetivos na base de uma auto-organização possível, que articule de uma forma mais consciente as suas heranças, as suas experiências formadoras, os seus grupos de convívio, as suas valorizações, os seus desejos e o seu imaginário nas oportunidades socioculturais que soube aproveitar, criar e explorar, para que surja um ser que aprenda a identificar e a combinar constrangimentos e margens de liberdade. Transformar a vida socioculturalmente programada numa obra inédita a construir, guiada por um aumento de lucidez, tal é o objetivo central que oferece a transformação da abordagem históricas de Vida (JOSSO, 2014, p. 58-59). 
Nessa pesquisa-ação participante, construída a partir da história oral e de narrativas de vidas de mulheres, as mulheres foram provocadas a pensar suas histórias de vidas no coletivo, potencializando a significação histórica e seu pertencimento como comunidade. Optamos por essa metodologia de pesquisa, pois na América Latina, a pesquisa-ação "[...] encontra-se vinculada, fundamentalmente, à perspectiva crítica de abordagem que tem como parte constitutiva de sua elaboração o engajamento sóciopolítico e a ação emancipatória, limitando desta forma o espectro de abrangência da pesquisa-ação (ENGERS, 1994, p. 86). Ademais, o curso que estamos inseridas foi construído a partir da Educação Popular ${ }^{7}$, voltado para os povos do campo.

A educação é permanente não porque certa linha ideológica ou certa posição política ou certo interesse econômico o exijam. A educação é permanente na razão, de um lado, da finitude do ser humano, de outro, da consciência que ele tem de sua finitude (FREIRE, 2001, p.12).

Assim, buscou-se compreender quem são as mulheres dos quilombos de São Lourenço do Sul/RS? Como vivem? Como se compreendem como pertencentes a uma comunidade? No que trabalham? Como são seus cotidiano? Quais são suas histórias de vida? Elas estudam? Fazem trabalhos artesanais? O que pensam sobre si mesmas? Quais desafios enfrentam na sociedade que vivem? Sofrem preconceitos? O que sonham? Essas são algumas questões que foram trabalhadas junto com mulheres que compõem a diversidade de povos tradicionais que vivem nos quilombos de São Lourenço do $\mathrm{Sul} / \mathrm{RS}$.

$\mathrm{Na}$ imagem 1, temos algumas das mulheres que participaram da pesquisa. Junto com a bonequeira quilombola Adriana da Silva Ferreira, temos as quilombolas brancas e negras, moradoras do Quilombo do Rincão das Almas mostrando as bonecas negras que confeccionaram durante a pesquisa-ação.

\footnotetext{
${ }^{7}$ Cabe destacar que Graziela Rinaldi da Rosa (autora) é professora da Disciplina de Educação Popular, na Universidade Federal do Rio Grande, militante feminista e educadora popular. Tem se dedicado a estudar e investigar as contribuições das mulheres nesse campo, e tem desenvolvido trabalhos com mulheres em diferentes comunidades, numa perspectiva emancipatória e feminista.
} 


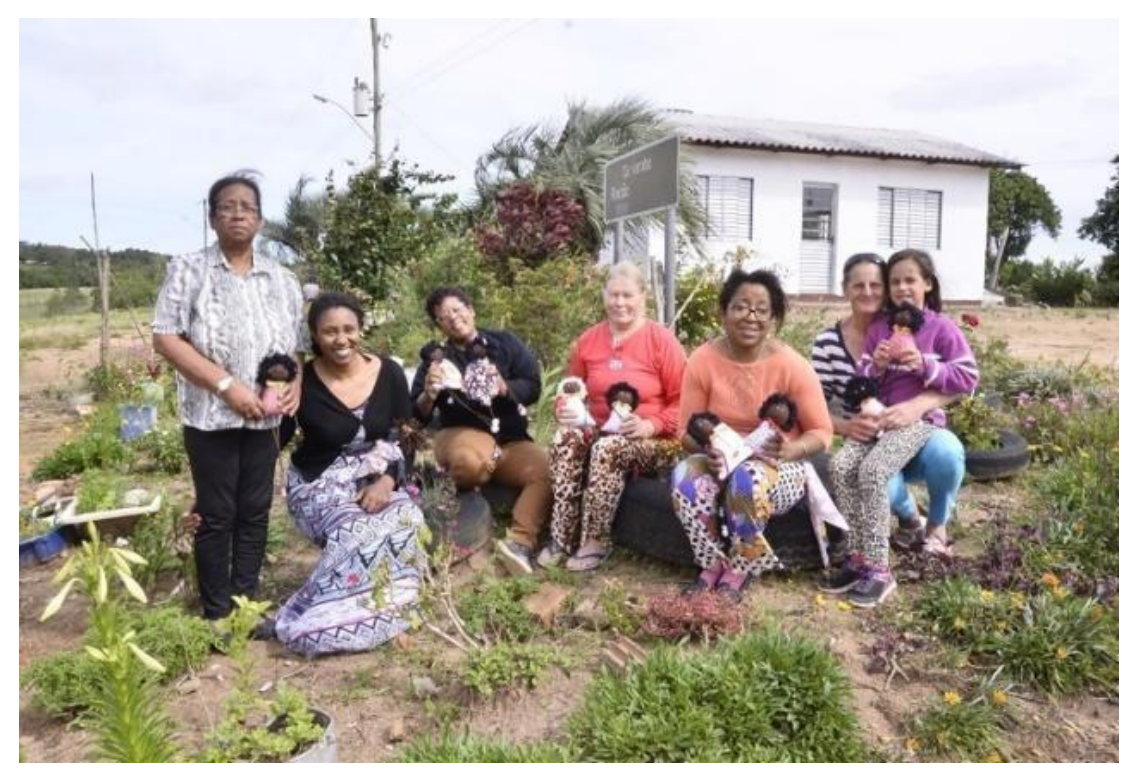

Fonte: Acervo da pesquisa "Mulheres dos Quilombos de São Lourenço do Sul” (2018)

Aqui, conseguimos apresentar algumas falas dessas mulheres que vivem nos quilombos, para que possamos conhecer um pouco sobre suas histórias de vidas e suas realidades. Trata de um trabalho que não se esgota facilmente, mas que nos motiva a seguir em diálogos com as mulheres de povos tradicionais quilombolas e a seguir aprendendo com as mulheres negras e seus feminismos, pois:

Pensar em feminismo negro é justamente romper com a cisão numa sociedade desigual. Logo, é pensar projetos, novos marcos civilizatórios, para que pensemos um novo modelo de sociedade. Fora isso, é também divulgar a produção intelectual de mulheres negras, colocando-as na condição de sujeitos e seres ativos que, historicamente, vêm fazendo resistência e reexistências (RIBEIRO, 2019, p. 15).

Desconhecemos qualquer trabalho de pesquisa que tivesse criado a metodologia de pesquisa-ação participante a partir da confecção de bonecas negras, especialmente com grupos de mulheres de quilombos. $\mathrm{O}$ trabalho com bonecas de pano são comuns na América Latina, e tem sido objeto de estudos no campo da educação popular. São bonecas de trapo, bonecas Zapatistas, bonecas indígenas feitas de palhas, e bonecas de cerâmicas, por exemplo.

As bonecas estão presente nos artesanatos de povos originários/tradicionais em toda latinoamérica. Elas representam as mulheres desses povos. Algumas na cor do pano, outras na cor das roupas, nas crianças que carregam nas costas, nos adornos, nos tecidos, ou outros materiais que as mulheres utilizam para tecer. 
A filósofa Mexicana Eli Bartra, que conheceu o trabalho da Quilombola/bonequeira Adriana ${ }^{8}$, em um dos congressos que fomos, a convidou para realizar seu curso de mestrado no México. Essa professora/pesquisadora, tem se dedicado a pesquisa sobre "Arte popular e Mulheres na Arte Popular".

Citamos Bartra (2005, p. 151), quando se refere às bonecas:

La función de estas muñequitas no es práctico-utilitariasólosirven como unrecuerdo de la lucha en Chiapas para nacionales y extranjeros. Son una curiosidadchiapaneca, igual que loeranlasmuñequitas no zapatistas que hacían antes y que todavíamanufacturan. Sonel equivalente de lasmuñecasregionales (conel traje típico del lugar) que se hacen y se vendenenmuchas partes del mundo. Sirvenbásicamente de adorno. No sonjuguetes para pequeños de ningún lado, no cumplenlas funciones de lasmuñecas que se usan para jugar. Los compradores son personas que, de alguma medida, simpatizanconel EZLN o conla lucha de los indígenas en Chiapas y estos objetos representanun símbolo de justicia y libertad.

Como podemos ver, há uma identificação sócio-cultural e/ou política quando nos simpatizamos com as bonecas artesanais, feitas na maioria das vezes por meninas e mulheres. As bonecas quilombolas, proporcionaram diálogos emocionantes durante as rodas em diálogos. Nelas, as mulheres revelaram suas histórias de vidas, problemas enfrentados, fizeram denúncias, relataram os descasos com os quilombolas e passaram a ter um olhar crítico ao meio em que estão inseridas, especialmente sobre o seu papel na comunidade, da importância de si mesmas para a história da comunidade quilombola, e da relevância de seus trabalhos, saberes e fazeres.

Assim, o ser mulher-negra quilombola foi instigado, da mesma forma que os encontros nos proporcionaram pensar sobre o "ser quilombola branca". Nesse sentido, todas nós, pesquisadora, oficineiras, bonequeira e mulheres das comunidades quilombolas, aprendemos juntas a conhecermos mais sobre nós mesmas.

\section{Conhecendo as histórias de vidas de mulheres quilombolas e os percursos de uma pesquisa}

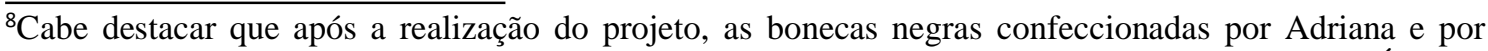
outras mulheres que participaram do projeto já estão pelo mundo. Temos notícias que foram para Áustria, Chile, Argentina, México e outros. Isso se deve ao fato da visibilidade da pesquisa-ação participante, e também da atuação e protagonismos das envolvidas em outros espaços, como feiras, exposições, eventos científicos e outros.
} 
Um sonho que eu tenho pro quilombo que cada vez melhorasse mais, que mais gente participasse, tem muitos que não acreditam, acham que é bobagem, mas eu acho que é uma coisa muito boa né, porque assim... que tivesse mais... uma coisa... uma renda... pra quando uma pessoa precisasse, tivesse como contar com ajuda do quilombola. (Neusa Beatriz Mourão, 2019, Acervo da pesquisa)

A pesquisa "Mulheres quilombolas de São Lourenço do Sul: Identidades, vivências e memórias", foi realizado no período de 2017 a 2019 (tendo sido aprovado no edital para Jovens Doutores/as- Programa Primeiros Projetos, da FAPERGS/CNPq -

ARD/PPP 2014). Foram realizados cinco encontros pré estabelecidos para cada Comunidade, envolvendo cerca de 40 mulheres e 10 meninas que vivem nos quilombos.

Devido ao envolvimento das mulheres com a pesquisa-ação participante, a disponibilidade da equipe de pesquisa e das mulheres pesquisadas, esse número de encontro se diferenciou para cada comunidade. As mulheres tinham outras demandas, algumas estavam envolvidas com a agricultura, outras com a casa e problemas pessoais, e tinha também aquelas que receberam a aprovação da habitação, e estavam construindo suas casas com suas próprias mãos, como foi o caso da Comunidade Quilombola do Monjolo. Como já havia constatado Rubert (2005, p. 61), “a melhoria nas moradias é uma das principais reivindicações da comunidade, que se ressente também da completa ausência de energia elétrica e do precário abastecimento de água potável (vertentes e cacimbas)".

Alguns encontros tiveram a presença da assessoria de uma advogada negra ${ }^{9}$, uma policial civil que desenvolveu estudos sobre violência contra as mulheres no campo, para que fossem abordados temas como direitos e violência contra as mulheres.

A partir dos diálogos estabelecidos, foi possível ter conhecimento de saberes, vivências e histórias de vidas das mulheres quilombolas dessas comunidades. Nãoconseguimos abranger a totalidade de moradoras das comunidades quilombolas, no entanto tivemos a surpresa no decorrer da pesquisa do envolvimento significativo delas, e também da inserção de meninas adolescentes, que também quiseram se inserir e deram depoimentos de grande relevância. Em um movimento de "hacerhistoria desde abajo y desde elSur" (CARRILO, 2017), é que esse trabalho de pesquisa se construiu.

${ }^{9}$ A advogada participante da pesquisa escreve em seu artigo sobre os encontros. Ler Ferreira (2019). Ver referências. 
As mulheres demonstraram força e liderança, ao mesmo tempo que compartilham seus conhecimentos e saberes populares, e nos ensinaram e emocionaram a cada instante frente a superação do racismo que enfrentam em seus cotidianos. Como disse Georgina Nunes (2019, p. 151):

Muitas das mulheres-liderança que se pôde conhecer durante mais de uma década de trabalho voltam à cena para serem melhor desveladas. Elas têm como característica primordial a vivência na sua comunidade de origem onde atuam como professoras e representantes de diversas entidades políticas: associação Quilombola, Grupos de Mulheres, Organizações Não Governamentais, Federações Nacionais e Regionais.

São mulheres que denunciam os racismos e se auto-organizam, criando estratégias de lutas e (re) existências frente aos preconceitos, o patriarcado e racismos, em busca da superação dos problemas que enfrentam, como por exemplo, o desemprego, falta de escolas para suas crianças, falta de água de qualidade, habitação, escolas e transporte.

\section{Mulheres- negras e mundo do trabalho}

A maioria das mulheres dos quilombos carregam um sorriso no rosto, que nos surpreendem. Denunciam as desigualdades e os preconceitos que sofrem. Falam do que necessitam, da falta de trabalho, de escolas de educação infantil, da distância das escolas. Acreditam em dias melhores, e são gradas pelo que possuem. Orgulhosas de suas histórias de vidas, nos contaram o que viveram, o que plantam, o que sonham.

A imagem que segue, mostra as mãos de uma quilombola, do Quilombo da Picada, que na ocasião estava mostrando para a pesquisadora a flor de palha, uma espécie de Margarida, que é antiga, e que as mulheres do Quilombo cuidam. Imagem 2. Mãos que plantam (flores do Quilombo da Picada/São Lourenço do Sul-RS). 


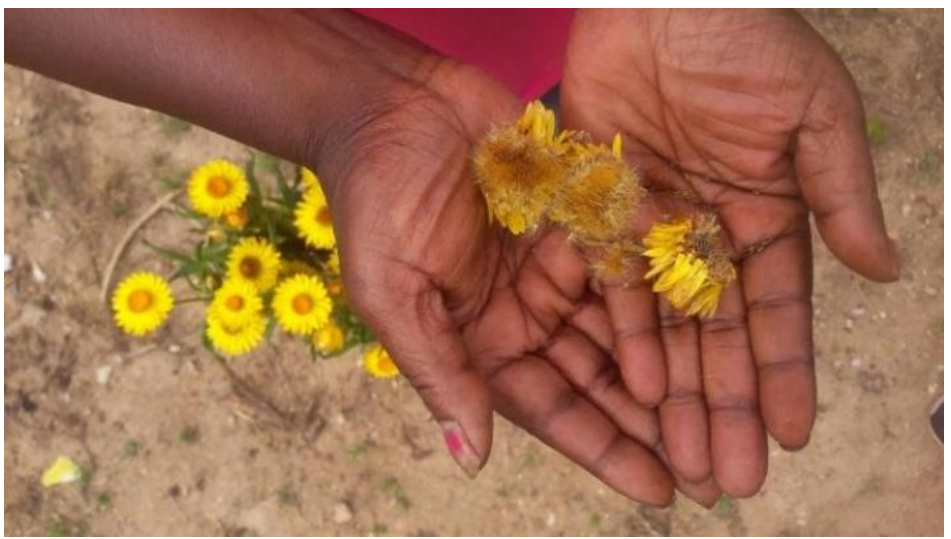

Fonte: Fotografia de Graziela Rinaldi da Rosa (acervo da pesquisa)

Seus sorrisos escondem uma triste realidade. As quilombolas como a maioria das mulheres rurais em grande parte trabalham na agricultura junto de seus pais, e da família, e cuidam das suas casas e filhos/filhas. São elas que permanecem nas comunidades, e poucas conseguem sair para trabalhar ou estudar, mas quando saem, gostam de retornar para as comunidades.

Mesmo aquelas que conseguem sair das comunidades para estudar, possuem grandes dificuldades de conseguir trabalho. A filósofa negra Angela Davis, em seu livro "Mulheres, cultura e Política" problematiza essa realidade, que é a mesma, e só muda o contexto, o local, o período histórico.

A falta de empregos é um problema de singular importância para a população jovem, principalmente a juventude negra e de outras comunidades racialmente oprimidas. Trata-se de uma preocupação para as mulheres jovens, em especial as de minorias étnicas. Quantas já imaginaram que, após a formatura, haverá um emprego criativo e com ótimo salário esperando por vocês - ou que uma bolsa de estudos permitirá que façam faculdade? Muitas de vocês, sem dúvida. Mas vocês estão lidando com um governo que não se importa nem um pouco com a juventude e com o seu futuro (DAVIS, 2017, p. 147).

No município de São Lourenço do Sul, não há políticas públicas voltadas para essas mulheres. Rubert (2005, p. 61), constatou que a principal fonte de renda das 
famílias, era "o trabalho como diarista em lavouras e fazendas das redondezas, embora plantam hortas e pequenas roças de subsistência nos pequenos terrenos que possuem (aproximadamente 1 ha por família). As mulheres seguem nos mesmos trabalhos. Poucas conseguiram cursar uma Universidade, e essas que conseguiram, estão atuando especialmente no campo da Educação. Poucas se graduaram, e algumas estão cursando Licenciatura em Educação do Campo, na Universidade Federal do Rio Grande, campus de São Lourenço do Sul/RS.

Carmen Rodrigues Quevedo,do Quilombo do Torrão,em seu relato denuncia a exploração da mão de obra feminina-negra e quilombola:

Estamos muito feliz assim, espera que as pessoas continuem assim como a gente é, e os outros também, né. Tanto como nosso quilombo aqui do Torrão, no Monjolo, no Rincão, Quilombo da Picada, se tiver, recebe essa gente com muito orgulho, de portas aberta que a gente precisa deles. Se não fosse eles [se referindo aos projetos de instituições] nós não tava aqui, nós tava assim trabalhando pros colono com a miséria que eles pagam, que eles não gostam de pagar muito pro negros, e eles perguntaram assim pra mim: "a gente pede pro fulano vir e o fulano não quer vir", ai eu penso assim, como tu vai sair de uma casa pra trabalhar por dez, quinze pila? Não adianta, tu não consegue comprar nada (Carmem Rodrigues de Quevedo, 2019. Acervo da pesquisa).

No interior os grandes produtores ainda vivem como no colonialismo. Há muita exploração de mão de obra, especialmente aquilombola, negra e feminina. Pagam pouco para trabalhar e exigem uma carga horária grande, em condições péssimas. $\mathrm{O}$ relato de Carmem mostra uma realidade comum que os/as quilombolas sofrem em todas as comunidades.

As mulheres denunciam a falta de escolas para deixarem seus filhos e filhas, para que possam estudar e trabalhar, e por isso permanecem atuando nas lavouras, geralmente para os/as pomeranos/as, e atuam em plantações de fumo, recebendo pouco.

Ainda são poucas que dizem dão o basta para tal exploração, e que buscam alternativas melhores de trabalho e estudo, quando estas existem. Por isso, são as mulheres quem mais sofrem com o racismo, e com as desigualdades sociais no campo. Algumas se negam a servir esse sistema exploratório e colonialista, como é o caso de uma liderança da comunidade do Torrão:

Sempre me perguntam, "quer trabalhar?" "trabalho!", faço o preço, faço, se achou muito, trabalho sozinha. Eu já trabalhei de peão, mas agora tão cedo não me pego pra trabalhar de peão, por causa que tem família, tem que cuidar da casa, tem que cuidar bicho, 
não adiante, porque muita gente sai de manhã e volta de noite, ai tu chega em casa quer descansar tem que dar um monte de coisas que igual o meu caso. (Carmem Rodrigues de Quevedo, 2019, Acervo da pesquisa).

Segundo Paulino (2016), é difícil comparar o trabalho das mulheres rurais com o das mulheres urbanas porque na cidade se recebe salário e no campo o trabalho é familiar.

No caso das mulheres que vivem nos quilombos, muitas não tem renda própria. Com a oportunidade de ter o aprendizado de um trabalho artesanal (no caso da pesquisa-ação participante foi a confecção de bonecas negras) pôde proporcionar isto, além de toda a questão da representatividade em confeccionar bonecas negras. Tal confecção de bonecas faz com que as mulheres olhem para si e suas filhas, netas e sobrinhas, e valorizem sua cultura, suas crenças ${ }^{10}$, seus saberes e seu fazer artesanal.

Esse novo olhar feminista e anti-racista, ao integrar em si tanto as tradições de luta do movimento negro como a tradição de luta do movimento de mulheres, afirma essa nova identidade política decorrente da condição específica do ser mulher negra. $\mathrm{O}$ atual movimento de mulheres negras, ao trazer para a cena política as contradições resultantes da articulação das variáveis de raça, classe e gênero, promove a síntese das bandeiras de luta historicamente levantadas pelos movimento negro e de mulheres do país, enegrecendo de um lado, as reivindicações das mulheres, tornando-as assim mais representativas do conjunto das mulheres brasileiras, e, por outro lado, promovendo a feminização das propostas e reivindicações do movimento negro (CARNEIRO, 2011, p. 2).

Nas comunidades quilombolas Coxilha Negra, Torrão, Monjolo, Rincão e Picada foram organizadas oficinas para o aprendizado da confecção de bonecas, motivando elas para a obtenção de uma renda, através do trabalho artesanal. As rodas de conversas com oficinas de bonecas negras foramestratégias metodológicas, a fim de nos reunirmos nas comunidades, para confeccionar bonecas, costurar e dialogar acerca de suas vivências e suas inquietudes. Como podemos ver na figura 3, as mulheres dialogavam com a pesquisadora, enquanto confeccionavam as bonecas negras, no Quilombo Rincão das Almas.

${ }^{10}$ Sobre "Religiosidades em Comunidades Quilombolas", ver Rubert (2016). 


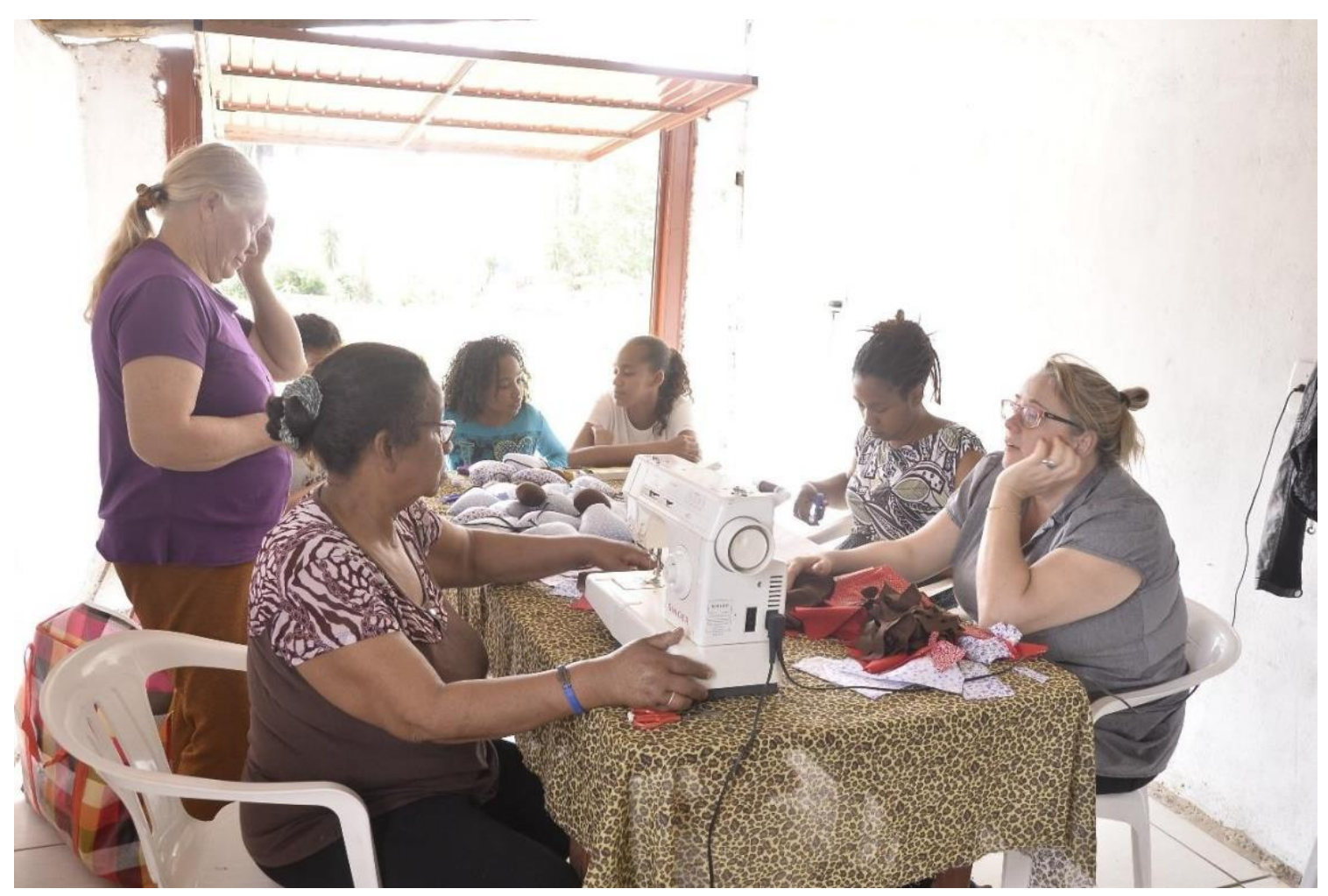

Fonte: Acervo da pesquisa.

\section{Mulheres negras e racismo}

Foi um grande aprendizado ouvirmosos relatos dessas mulheres e adolescentes,que compartilharam suas memórias, vivências e histórias de vidas. Foram dias intensos e de muita cumplicidade, carinho e respeito, procurando cada uma dar o melhor e procurando entender suas existências como mulheres, meninas e jovens negras quilombolas.

As quilombolas mais jovens, falaram com mais propriedade dos preconceitos que sofrem. Denunciaram o racismo e a falta de conhecimento nas escolas que frequentam sobre seu povo e suas histórias. Sabemos que:

O Brasil desenvolveu e adota o racismo mais eficaz do mundo: aquele cujo funcionamento não pode ser aferido, aquele que não tem um padrão, não é palpável nem evidente. Ele existe e é praticado e sofrido todos os dias, mas não tem peso nem medida. Assim, nós temos no Brasil uma sociedade produzida como utopia, feita para parecer que, aqui, entre negros e brancos, tudo vai bem, reina a paz racial e toda e qualquer equação étnica está bem resolvida. Artificialmente os brancos parecem amigáveis com os negros - com os negros que não lhes fazem concorrência econômica, política ou social. Brancos e negros só trabalham juntos fisicamente (OLIVEIRA, 2006, p. 11). 
Geisa Ferreira (Imagem 4) denuncia a falta de respeito com seu povo. Essa jovem, fala de bullyng, do racismo na escola, e relaciona com o fato de ter muitos pomeranos na cidade de São Lourenço do Sul.

Ser jovem quilombola, não é fácil mas não é difícil. Pra mim ser uma jovem quilombola, não é bom, nem é ruim. Tem vantagens, mas tem desafios. Desafios assim para mim, jovem, guria e negra: escola trabalho e convivência... Escola é racismo, é bullying, tem muita coisa. Porque aqui é onde tem muito pomerano, alemão... Então, não tem... Eles não respeitam a gente ser como a gente é...eles não aceitam. O bom... é que eu sou, eu me aceito. O lado bom de ser quando tem reunião a gente se sente bem, pois é o nosso meio, quando a gente se junta, é um momento único. Tem várias coisas que ser quilombola me trouxe, tenho orgulho de ser negra, tenho orgulho do meu cabelo, tenho orgulho do meu tom de pele, porque eu me acho única. Só se fazer um clone de mim pra ter outra igual. Cada um tem seu eu, suas marcas, como mulher, como quilombola, as dificuldades tem sido emprego e escola. É bem complicado. (Geisa Ferreira, 2019, Acervo da pesquisa)

Como uma jovem do Quilombo da Coxilha Negra, ela tem orgulho de ser negra, do seu cabelo e de sua pele.Geisa é uma líder nata. Filha do atual presidente do Quilombo, ela possui uma fala convicta do que acredita e espera para sua comunidade. A partir de sua inserção no projeto, Geisa passou a participar de outras atividades fora da comunidade. Foi para Porto Alegre apresentar o projeto, e junto com sua mãe está fazendo bonecas negras e comercializando elas.

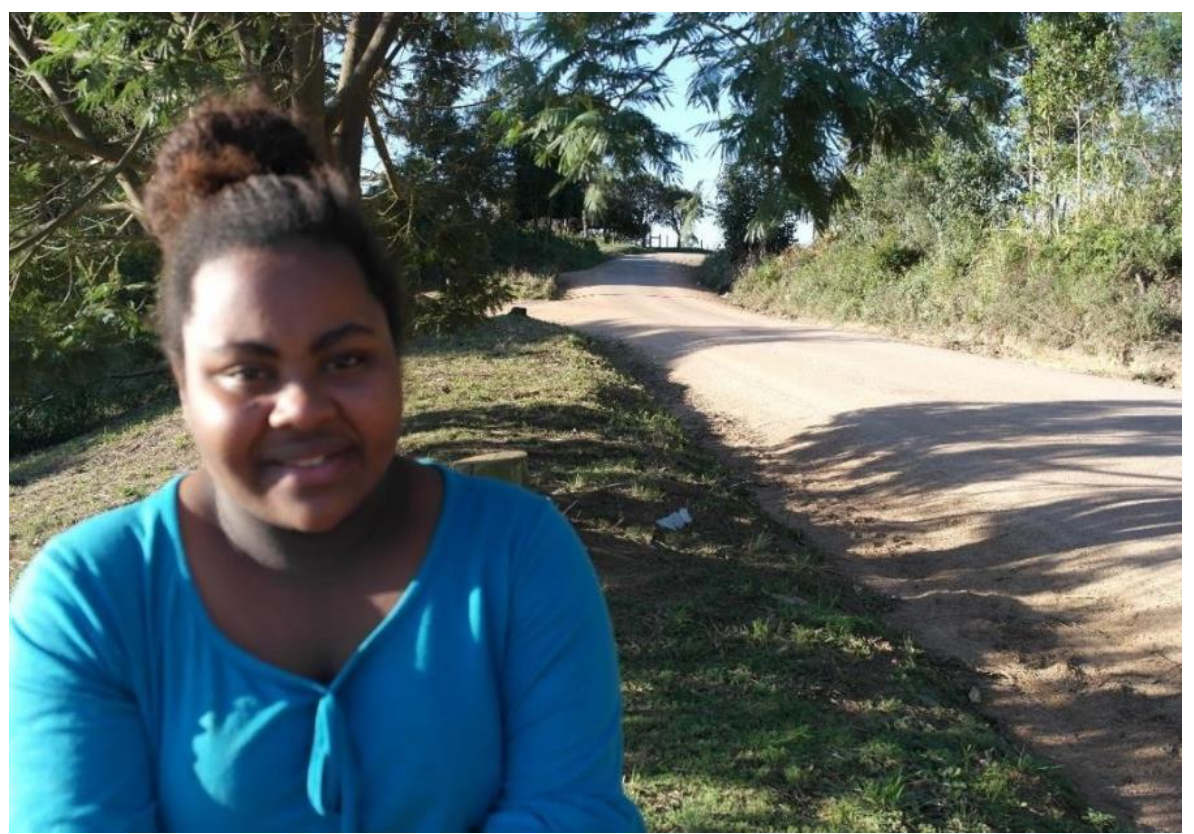

Fonte: Fotografia de Graziela Rinaldi da Rosa (Estrada do Quilombo) 2017 
Emily, uma jovem do Quilombo Rincão das Almas, de apenas 14 anos, também relata como é ser uma menina negra no meio escolar:

Tem coisas no colégio que nem lembram dos quilombolas, mesmo só na consciência negra, falam muito pouco, falam mais é dos escravos, sempre tentam relembrar a raça negra num álbum diferente como escravo, escravidão... porque lá num tempo tu era escravo de alguém, pra as pessoas podiam lembrar mais disso tem gente que lembra bastante, tem quem não lembra.Eu já ouvi boatos... "ah, como teu cabelo é feio" ... Às vezes tu fica quieta, tenta não responder, às vezes tu não te segura, já respondi pra várias pessoas, as pessoas tentam falar "tua pele é escura, tua pele é isso", as pessoas não têm consciência, tem preconceito! Tu tem a mesma coisa que ela, pessoa branca e a morena, tudo... olho, cabelo, boca. Uma coisa que as alemoa não tem: tu é julgada por uma coisa que tu não pediu... Aposto que as pessoas não pediram pra ser negras, nascer morenas, mas essas que nasceram tem orgulho da pele, tem orgulho do cabelo, tem orgulho de ser o que é, nunca deixo de ter orgulho de ser mulata. (Emily, 2019, Acervo da pesquisa).

A menina Emily revela o descaso de como é tratada a história do povo negro nas escolas. Ela sabe que São Lourenço do Sul tem uma história local de protagonismo negro, e da importância da negritude e dos quilombos, e que a mesma é linda e riquíssima, mas que é tratada com total invisibilidade. Ela denuncia que além de abordarem nas escolas apenas o tema escravidão, fazem isso só em novembro por conta da lei 10639/03.

Os/as estudantes que não tem conexão com a história da população negra, e não sabem nada da cultura, da religião, dos quilombos de São Lourenço do Sul, principalmente da própria história local, não tem conhecimento muitas vezes das comunidades quilombolas. Nesse sentido, "talvez o maior desafio não só das comunidades quilombolas mas de todos os brasileiros, seja combater o preconceito, seja ele religioso, de raça ou de classe social (LOBÃO,2014, p. 120).

Mariela Centeno, uma jovem mãe, relata a dificuldade de sair do quilombo porque não tem como deixar os filhos e a casa para trabalhar ou estudar fora. Fala também da necessidade delas terem empregos:

As mulheres não tem grande oportunidade de emprego, porque é mais os maridos que eles saem pra fora, para trabalhar. A mulher é mais em casa, cuidando da casa dos filhos, que mais falta é uma renda para as mulheres. Um emprego, que aí ia mudar bastante a nossa realidade.(Mariela Centeno, 2019, Acervo da pesquisa.) 
A fala de Mariela (imagem 7) evidencia que sendo mulher num contexto geral já se enfrenta muitas dificuldades por causa do preconceito de gênero, e isso piora muito quando se torna mãe, e mais ainda quando se é mulher negra de comunidade quilombola em uma cidade em que a valorização da cultura pomerana é forte, e onde um dos requisitos para se trabalhar no comércio local é falar a língua pomerana. Nesse caso, a exclusão é racial e cultural.

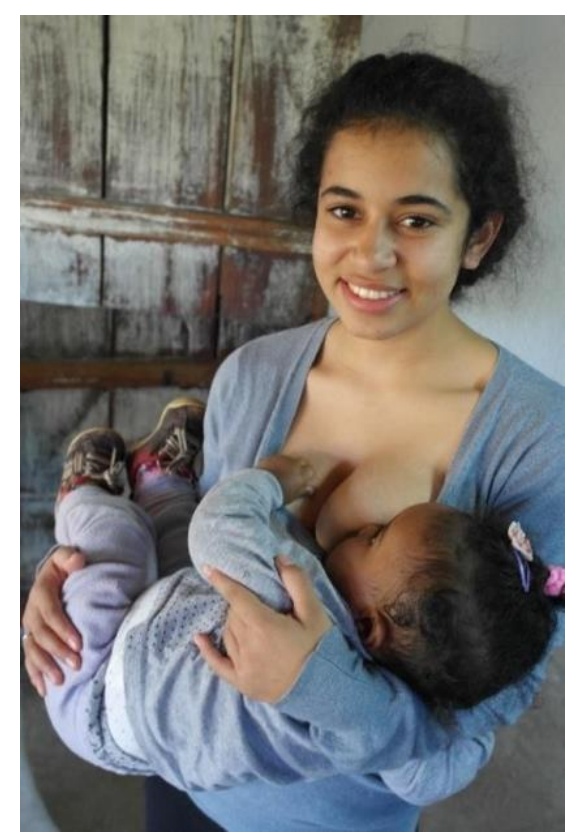

Fonte: Fotografia de Graziela Rinaldi da Rosa (Acervo da Pesquisa)

\section{Memória, Ancestralidade e mulheres negras quilombolas}

Vera Lúcia de Souza, mais conhecida como Vera Macedo é uma das líderes do movimento negro e grande responsável pela caminhada de reconstrução e reconhecimento do quilombo das Nascentes, fala enquanto sua caminhada e das dificuldades de ser mulher negra:

Não é fácil ser mulher negra, porque a gente encontra todas as dificuldades. As dificuldades na saúde, na educação, no meio de trabalho, mercado de trabalho. Nas próprias relações é complicado ser negra, é difícil ser negra. A não ser negra consciente, empoderada de sua negritude, consciente de ser negra. Porque aí a gente consegue trabalhar com esses problemas que a gente encontra. Uma mulher não

Revista Diversidade e Educação, v.7, n.especial, p.133-164, 2019. Doi: 10.14295/de.v7iEspecial.9530 E-ISSN: 2358-8853 (cc) EY-NC-SA 
consciente somente preta - como eu digo, que aí a mulher não é negra é preta, ela não se auto reconhece como uma mulher negra, então sofre muito... E ela sofre sem saber que dor é essa. São as dores de ser negra, é a herança da escravidão, né, que nem a gente diz. Então, é esse legado da exclusão total da mulher no mercado de trabalho, na educação, na saúde. Em todos os meios né, das políticas públicas, que inclusive sendo própria para mulher negra, mas que há momentos que a gente sabe que eles não são "totais", vamos dizer assim (Vera Lucia de Souza, 2019, acervo da pesquisa).

Vera também fala sobre os quilombos e conta sobre a história de sua avó Maria Lina. Maria Lina nascida em 1884, quatro anos antes da abolição oficial da escravidão, nasceu livre pela fuga da sua avó que fugiu junto com mais doze negros. Durante sua vida andou e fez parte da formação de três quilombos do município de São Lourenço do sul, teve diversas profissões como trabalhar na agricultura para os donos das plantações o que hoje chamamos de peão, foi também benzedeira, parteira, curandeira. Maria Lina tinha uma conexão com a natureza muito forte, através dos animais, previsão do tempo e um vasto conhecimento de ervas medicinais.

Falar dos Quilombos de São Lourenço do Sul, é falar de Maria Lina. Sem falar dela não consigo falar dos Quilombos, Maria Lina é minha vó, morreu com 104 anos, aproximadamente 30 anos que ela faleceu. Ela começou a contar as história dos Quilombos, ela me falava, contava pra nós, o que era os quilombos. Não se conhecia essa palavra "quilombo" ainda, mas chamavam de comunidade, de junção... Era dessa forma, eu aprendi a me conhecer como mulher negra também, desde criança a gente convive com essa vó, que nasceu livre, mas livre pela fuga da vó dela. Aí através da fuga da vó dela, eles se aquilombaram. Eu acredito que tinha vindo, ela não sabia dizer direito de onde era, isso 60 anos atrás quando ela nos contava. Inclusive, não era nem bem definido os espaços com os nomes atuais que é hoje. Ela usava os nomes que eles conheciam da época, ela falava muito das mulheres negras que comandavam o seu grupo. Eram as mulheres que guardavam as sementes, era as mulheres que muitas vezes faziam as hortas que eles plantavam, era elas que colhiam, era elas que muitas vezes criavam os animais, que eles muitas vezes criavam pra comer. $\mathrm{E}$ a Maria Lina nasceu num quilombo, formado por uma fuga de 12/13 negros. Isso ela contava. Ai eu vim conhecer esse espaço, há anos agora atrás, é que eu vim conhecer. Muito pouco tempo até que eu vim conhecer. E aí a gente começou a se fortalecer esses laços com a comunidade quilombola, com as comunidades quilombolas. A partir de que também a gente começou a militância no movimento negro, a gente começou a clarear muitas ideias que a gente tinha, mas não se achava o fio da meada. A partir daí, a gente começou a visitar as comunidades quilombolas, veio também a faculdade do Paraná, e foi o primeiro que foi fazer visita nos quilombos e a gente foi junto, a partir dali a gente começou a fazer mais visita, conversar com essas pessoas. Encontrei os parentes, porque a vó deixou. Porque a vó deixou lá seus parentes até chegar aqui dentro da cidade, onde eu nasci, não era ainda 
esse povo todo... Não era cidade ainda, era interior... Na praia, mas considerado interior porque era bem longe de tudo (Vera Lucia De Souza, 2019, Acervo da pesquisa).

O relato de Vera Macedo (Imagem 6) mostra a grande importância das mulheres de povos tradicionais em suas comunidades desde quando surgiram e até os dias de hoje. Elas continuam sendo as grandes lideranças, guardiãs de conhecimento, guardiãs das sementes. Conhecem sobre os alimentos, suas formas de preparo, as ervas medicinais.

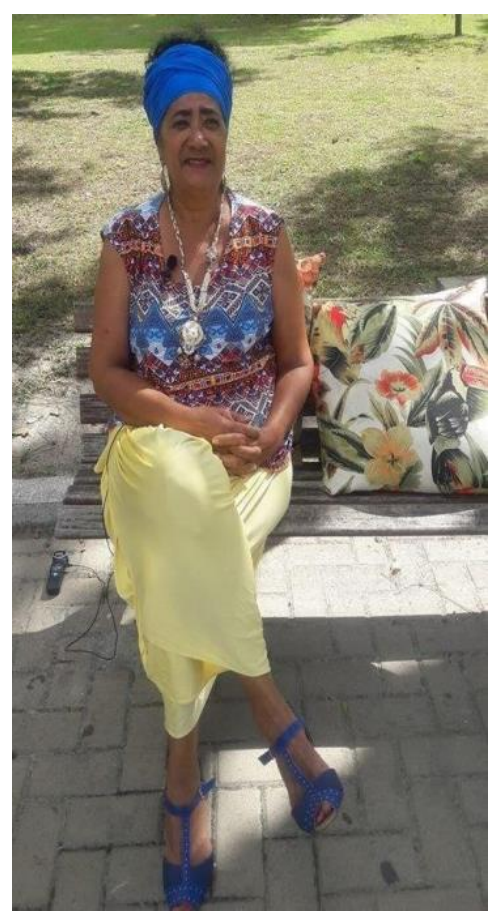

Fonte: Acervo da pesquisa/2019

Vera Macedo ressalta o protagonismo das mulheres, e do movimento de consciência negra. Desde sua fundação nos anos 1980 o movimento de consciência negra de São Lourenço do Sul conta com suas lideranças femininas, são essas mulheres negras remanescentes quilombolas que ao passar dos anos foram organizando o movimento, e estiveram à frente das lutas, da busca pela própria história dos negros(as). Organizaram e organizam eventos, encontros e formações com as comunidades e escolas. 
Sabemos que o auto reconhecimento enquanto povo tradicional precisa ser trabalhado nas comunidades, além de discutir a importância do quilombo para a história do Brasil e a própria história de vida destas mulheres como patrimônio. Além do (re)conhecimento de seus saberes e fazeres como cultura, uma verdadeira história viva. (ROSA, 2019, p.53)

Assim como Maria Lina foi lembrada por sua neta, Vera, liderança há cerca de 30 anos do movimento de Consciência Negra Local, mulheres de outros quilombos destacam a importância de suas ancestrais para a história dos Quilombos. No Quilombo da Picada, Sandra (Imagem 8) destacou o protagonismo de sua avó Ana Dorinha Ferreira, mais conhecida na comunidade como "Morena". Nascida em 14.01.1930, e falecida em 27.02.2006. Trabalhou na lavoura para se sustentar e sustentar seus filhos/as.

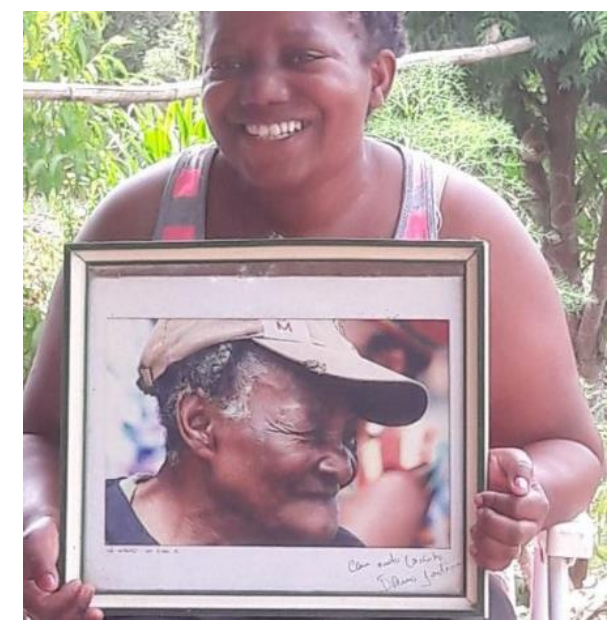

Fonte: Fotografia de Graziela Rinaldi da Rosa (acervo da pesquisa)

No Quilombo Rincão das Almas, a dona Eva Maria Soares Furtado Mourão falou da importância que sua mãe tinha na comunidade e das dificuldades que passava na sua infância:

Ontem eu tava me lembrando porque a minha mãe às vezes não tinha o que colocar no prato e não tinha semente. Ela ganhava cozinhadinha de batata, da casca ela enterrava, dali nascia uma batatatinha bem pequena e ai ela tirava mudinha. Daí outra que minha mãe se tornou benzedeira, parteira, nesse Rincão ela foi parteira da maioria, benzedeira, a sinhá dela que chamava, benzia encalho de quebrante, ela já atendia as mulheres no parto, já benzia e batizava e tudo que eu aprendi, aprendi com ela, muita coisa, como ervas de chá, meu avô era bugre, era índio, fui aprendendo. Então, a gente aprendeu a criar os filhos com os quilombolas que se dizem, com sacrifício, com 
sacrifício pra criar os filhos.Às vezes não tinha alimento, minha mãe me ensinou muito alimento, ontem eu me lembrando coisa antigas com batata doce, às vezes ela dizia: "hoje não tem pão", tinha que tomar café com batata doce, ou café com mandioca pra deixar bolacha assim ela fazia pros irmão mais mocinho e nos passava a batata e mandioca pra deixar pros mais pequeno. Ai ela saia a trabalhar nas granja, cortar arroz e eu ficava com meus irmãozinhos pequenininhos. (Eva Maria Soares Furtado Mourão, 2019, Acervo da pesquisa.)

As comunidades quilombolas são extremamentehumildes, hoje as pessoas nelas tem mais qualidade de vida devido algumas políticas públicas, como por exemplo a de acesso ao ingresso nas universidades, linhas crédito, bolsa escola, entre outras, mas no passado dificuldades como essas do relato eram comuns. Os quilombos esquecidos no

lugares remotos do interior de São Lourenço do Sul eram extremamente pobres e homens e mulheres sofriam muito com a falta do básico para sobreviverem. Hoje isso tudo foi amenizado, principalmente por causa das reivindicações vinda destas mulheres. O protagonismo das mulheres negras quilombolas é marcante. Elas são quem presidem das comunidades, que hoje possuem associações. Carmem Ieda Rodrigues do

QuilomboRincão das Almas, evidência bem na sua fala o protagonismo feminino nas comunidades quilombolas:

Nós mulheres assim... aqui dentro do quilombo a gente meio que ficava, sabe, indeciso com tudo, mas cotidiano das mulheres hoje dentro do quilombo assim, tem vários tipos de profissões diferentes, umas vão pra agricultura outras trabalham fora, tem a questão de muitas que não consegue trabalhar de novo, por causa dos filhos, ai tem os que vão pra escola, tem o pequeno que fica em casa, aquela coisa assim, mas eu acho que nós mulheres ainda estamos a frente. Eu concordo, hoje eu acho tudo mais fácil nessa parte, porque tipo estudar, por exemplo, a gente não tinha nem como, somente quando era raça negra. Como em vários lugares nem existe isso, hoje eu vejo que tu faz uma faculdade tranquila também, tudo isso se tem cotas pros quilombos, pra família quilombola, hoje tem vários benefícios e geralmente quem corre atrás disso é as mulheres, é ela que vão a luta, buscam os direitos. (Carmem Ieda Rodrigues, 2019, Acervo da pesquisa.)

Djamila Ribeiro (2018) diz que cada mulher pode criar em seu espaço de atuação formas de empoderar outras, e a pesquisa aqui apresentada contribuiu para tal feito, já que ela surge de um sonho da primeira aluna quilombola do Curso de Educação do Campo e de uma professora feminista que luta pela igualdade de gênero principalmente das mulheres de povos tradicionais que são as que sofrem com as 
maiores injustiças, discriminação, violências e falta de acesso a serviços públicos de qualidade.

A condição social da mulher negra requer uma análise particular devido as suas características bem específicas, marcadas por preconceitos e discriminações. As experiências vivenciadas por elas podem ser preservadas e utilizadas para transformar a realidade apresentada, através de muito esforço de forma consciente e coletivamente. (GRANDO, PEREIRA, CUNHA E FERREIRA, 2018, p. 118)

Lurdes Helena Ferreira de Quevedo, nos conta que nasceu no Quilombo do Torrão e o que fazia durante sua infância e como as coisas foram melhorando com a chegada da luz elétrica na sua comunidade:

Foi assim que a gente se criou com os pais da gente, a gente não se criou nos estudos porque a gente ia um dia e no outro dia não pra ajudarmos pais em cada que nós era pobre mesmo não tinha condições. De uns anos pra cá que a gente conseguiu luz elétrica, 2003. Foi melhorando nossa vida. Não tá bem melhor, mas ta muito melhor do que tava, conseguimos ter uma geladeira, televisão, ter uma casa melhor, a gente ganhou essa casa do projeto da Caixa Econômica Federal e foi ajeitando nossa vida... acho que foi isso aí. (Lurdes Helena Ferreira De Quevedo, 2019, Acervo da pesquisa)

Lurdes também fala de projetos e cursos que ao ver dela faz falta no seu quilombo:

É... Aqui no Quilombo a gente não tem quais serviços. É só na horta e dentro de casa, se a gente conseguisse ter... tivesse um curso tipo culinária. Nós já pedimos várias vezes... aproveitamento de alimento...já pedimos quantas vezes, mas nunca vieram fazer isso com nós, mas nunca foi permitido nosso projeto de aproveitamento de alimento. Era isso que eu queria que fosse, Pra gente aprender a fazer uma bolachinha, pra poder vender, um outro tipo de chimia, pra gente fazer chimia que chimia gente sabe fazer, mas pode ter outros que a gente não sabe, né. Isso ai que eu acho que era bom pra nós no quilombo. (Lurdes Helena Ferreira De Quevedo, 2019, Acervo da pesquisa)

Estes foram alguns dos tantos relatos destas mulheres. Alguns estão no documentário no qual o link está disponível nas referências.Com eles, podemos ter uma breve ideia de como se vive, quais as dificuldades encontradas e um pouco das memórias, histórias de vidas, e formação dos Quilombos de São Lourenço do Sul/RS.

\section{Para não concluir: algumas considerações}


Entre tantos relatos e partilha de saberes, essas mulheres com falas tão distintas e pessoais, nos evidenciam a concordância delas com relação às políticas públicas, que segundo elas, melhoraram a vida nos quilombos e oportunizaram acesso a direitos básicos, como à educação, luz, habitação.

Também consideram importante os projetos e pesquisas como essa, porque não entrou em suas comunidades com a intenção de extrair conhecimentos populares, mas que levam um retorno para as comunidades, além da visibilidade, e a valorização desses povos.

As mulheres quilombolas, também deixam evidente a relevância do aprendizado como as bonecas negras, que além de trabalhar com suas identidades, também se torna uma forma de obter renda.

A pesquisa demonstra que em todas as conquistas dessas comunidades, está presente o protagonismo feminino. São estas mulheres que mais reivindicam os direitos dos povos quilombolas, que têm mais estudos, que procuram se profissionalizar e também detém os saberes de seu povo, inclusive da história dos quilombos, e que passam de geração para geração.

O Movimento de consciência negra local possui um papel importantíssimo nesse protagonismo, e na valorização desses povos tradicionais quilombolas. Foram pioneiros/as na região, com trabalhos desenvolvidos nos quilombos, e nas escolas sobre o povo negro, e povo quilombola.

Há uma outra faceta desta pesquisa, que não foi possível abordar- as mulheres que saem dos quilombos e vivem nas cidades. Na verdade, esse seria tema para novas pesquisas, bem com o estudo dos índices de pessoas que saem, que entram e aquelas que retornam para viver nos quilombos, depois de ter trabalhado nas cidades, em busca de uma vida com mais estrutura, educação e acesso à direitos básicos.

As dificuldades encontradas na realização da pesquisa foram especialmente a distância para se chegar até as comunidades, e os horários pré-agendados, porque as mulheres dessas comunidades são donas de casa, agricultoras, diaristas e não possuem disponibilidade nos horários. Também, devido ao atraso do recurso do projeto, colidiu um ano da pesquisa, com o afastamento da pesquisadora para o seu estágio de pósdoutoramento. Mas, pode-se prorrogar o prazo e realizar todas as atividades previstas, exceto aquelas que as próprias mulheres não puderam realizar, visto que estavam 
envolvidas com a construção de suas casas (como foi o caso do Quilombo Monjolo), e outros projetos.No entanto, mesmo em meio a essas dificuldades éramos esperadas com os sorrisos das mulheres, em especial crianças, além do interesse delas.

A pesquisa possibilitou a criação de um documentário, que foi lançado por elas no IV Seminário das Mulheres- do Campo, das águas, florestas e cidades (2019) ${ }^{11}$, e também em algumas publicações em livros e revistas científicas, além de uma série de entrevistas de mulheres quilombolas (acervo da pesquisa), que poderão ser ainda melhor trabalhadas e analisadas.

Escutamos elas falando sobre suas trajetórias, sobre os problemas enfrentados nas suas comunidades, das dificuldades que passaram desde a infância, suas histórias de gerações passadas, sobre os preconceitos sofridos, violências. Suas reflexões sobre juventude negra, infância no quilombo, trabalho e educação das mulheres quilombolas, bem como dos processos de exclusão e o protagonismo feminino, entre tantos outros temas abordados.

O conhecimento adquirido com essa pesquisa vai além de um conhecimento acadêmico. Aprendemos juntas os saberes populares, um saber transmitido de gerações a gerações, que as mulheres pesquisadas (re)visitavam. E na medida que pensavam sobre si e seu povo, se questionaram sobre suas formas de vida e existência.As mulheres falaram sobre discriminação, violências sofridas tanto doméstica, patriarcal, institucional, destacaram que as mulheres negras são as maiores vítimas de feminicídio no Brasil.

Um relevante aprendizado que temos tido com esses diálogos com as mulheres negras e mulheres negras quilombolas, sejam elas militantes ou não, é sobre os feminismos, incluindo os feminismos negros, e alguns conceitos próprios desse campo, como por exemplo de "interseccionalidade", "lugar de fala" e racismo estrutural.

Como militantes feministas e estudiosas do tema, aprendemos com as mulheres negras e indígenas que o feminismo que estudávamos, não as representam, e assim,

\footnotetext{
${ }^{11} \mathrm{O}$ Seminário é coordenado pela primeira autora, com o protagonismo das líderes do Coletivo Feminista Dandaras/ FURG, e em parceria com diferentes instituições e organizações sindicais. Tem sido realizado desde 2015, com a realização conjunta com mulheres de diferentes coletivos e comunidades, bem como com mulheres de diferentes movimentos sociais, lideranças, educadoras, professoras, mulheres de cooperativas, líderes de quilombos, mulheres de povos de terreiros, pesquisadoras, estudantes, militantes, entre outras.Temos envolvido mulheres que atuaram/atuam na Marcha das Margaridas, no Movimento Sem Terra, via campesina, Marcha das Mulheres Indígenas, Marcha das Mulheres Negras, Marcha das Mulheres Indígenas, Marcha Mundial das mulheres Ciganas, Pomeranas, agricultoras familiares, pecuaristas, mulheres da cadeia produtiva da pesca, entre outras.
} 
passamos a ler e escutar mais as mulheres negras e indígenas, reconhecendo a necessidade de (re) pensar nossas epistemologias feministas, mesmo quando já vínhamos trabalhando com as fontes latinoamericanas.

Também, as mulheres passaram a terum olhar mais crítico sobre o seu papel dentro das comunidades e da importância delas nesse espaço, que muitas vezes são invisibilizadas e esquecidas, por esta sociedade patriarcal, racista e colonialista, que ao invés de valorizar a diversidade de povos, matam, discriminam de forma intolerante. Uma sociedade que não ouve essas mulheres, fazendo com que a todo o instante elas resistam a tudo e a todos, principalmente frente aos seus governantes.

Com a realização da pesquisa nas Comunidades Quilombolas de São Lourenço do Sul/RS, percebemos que os saberes que essas mulheres tem são saberes de pertencimento das comunidades. São vivências plurais de dentro das comunidades que elas têm que lidar diariamente.

Foi um grande desafio mas sobretudo um imenso aprendizado que essas mulheres negras quilombolas nos deram. Dentre eles, destacamos a humildade, a generosidade de estar partilhando experiências muitas vezes dolorosas.

É uma lição de vida, e um privilégio por estarem partilhando tamanha sabedoria e generosidade. Foram breves encontros, mas, intensos. As mulheres no início estavam tímidas e ao longo dos encontros foram se envolvendo, ficando a vontade e contando suas trajetórias.

Essa pesquisa-açãotambém tem muito o que contribuir para a Educação Popular, especialmente uma educação que se propõe a dialogar e ouvir as mulheres, seus saberes e vivências. Nesses encontros as estudantes puderam refletir sobre os seus papeis, como professoras e educadoras populares em formação, aprendendo a estar em comunidades, percebendo a importância disso para as mulheres. Afinal, o verdadeiro papel de uma educadora popular é ter empatia pelos outros seres, para tentar buscar meios de amenizar um pouco o sofrimento do outro ser, especialmente de nós mulheres, e das mulheres negras, que sofrem mais as mazelas das desigualdades sociais. Para que isso aconteça, temos que estar com o coração livre e em paz. Nos entregar à escuta, pois para poder ouvir o que o outro/outra tem a dizer de uma forma educada e respeitosa, é preciso primeiramente aprender que cada um tem a sua importância no mundo, para então aprender a compartilhar tudo o que foi vivenciado dentro da pesquisa, de uma forma humana e significativa. 


\section{Referências}

AKOTIRENE, Carla. Interseccionalidade. Coleção Feminismos Plurais. São Paulo: Sueli Carneiro; Pólen, 2019.

BARTRA, Eli. Mujeresenel Arte Popular. De promesas, traiciones, monstruos y celebridades. México: Universidad Autónoma Metropolitana, 2005.

CARNEIRO, Sueli. Enegrecer o feminismo: A situação da mulher negra na América latina a partir de uma perspectiva de gênero. São Paulo. Geledés. 2011 Disponível em:

https://www.geledes.org.br/enegrecer-o-feminismo-situacao-da-mulher-negra-naamerica-latina-partir-de-uma-perspectiva-de-generol. Acesso em outubro, 2019.

CARRILlO, Alfonso Torres. Hacerhistoria desde Abajo y desde elSur. Colômbia: Ediciones desde abajo, 2019.

DAVIS, Angela. Mulheres, cultura e política. São Paulo: Boitempo, 2017.

ENGERS, Maria Emília Amaral (org ${ }^{\mathrm{a}}$ ). Paradigmas e Metodologias de Pesquisa em Educação. Notas para Reflexão. Porto Alegre: EDIPUCRS, 1994.

FERREIRA, Evelin dos Santos. Direitos das mulheres do campo: avanços e retrocessos. In: ROSA, Graziela Rinaldi da. Mulheres em Movimento: perspectivas em educação, ativismo e empoderamento. Curitiba: Nova Práxis, 2019, p. 75-86.

FREIRE, Paulo. Política e educação: ensaios. São Paulo: Cortez, 2001.

GRADO, SaléteBeleni; PEREIRA, Lizanil da conceição Patrocínio; CUNHA, Tereza; FERREIRA, Waldineia Antunes de Âlcantara.Mulheres, territórios e identidades: despatriarcalizando e descolonizando conceitos. Curitiba: CRV, 2018.

GOMES, Flávio dos Santos. Mocambos e quilombos: uma história de campesinato negro no Brasil. São Paulo: Claro enigma, 2015.

JOSSO, Marie-Christine Josso. Experiências de Vida e Formação. São Paulo: Cortez, 2004.

KENSKI, Vani Moreira. Memória e Prática Docente. In: BRANDÃO, Carlos Rodrigues (Org.). As faces da Memória.Centro de Memória. UNICAMP, s/a, p. 101-114.

LOBÃO, Alexandre. Quilombos e quilombolas: Passado e presentes de lutas. Belo Horizonte: Mazza edições, 2014. 
MULHERES quilombolas de São Lourenço do sul. Direção de Graziela Rinaldi da

Rosa. São Lourenço do Sul, 2019. 1 video (66min.) Disponível em:

https://www.youtube.com/watch?v=AH3HUliU5zk\&t=1805s

NUNES, Georgina Helena Lima. Cartografias do Sul do Brasil e Pedagogias para uma Educação escolar Quilombola. In.: SOUZA, Edileuza Penha de; NUNES, Georgina Helena Lima; MELO, Willivane Ferreira de. Memória, territorialidade e experiências de educação escolar quilombola. Pelotas: Ed. UFPel, 2016, p. 159-179.

Lideranças Negras, Terra e Educação em Quilombos. In.: SILVA, Márcia Alves da; ROSA, Graziela Rinaldi da. (organizadoras). Pedagogias populares e epistemologias feministas latino-americanas. Curitiba: BrazilPublishing, 2019, p. 149-168.

OLIVEIRA, Eliana. Mulher Negra. Professora universitária- Trajetória, Conflitos e Identidade. Brasília: Líber Editora, 2006.

PAULILO, Maria Ignez. Mulheres rurais: Quatro décadas de diálogo. Florianópolis: Ed da UFSC, 2016.

RIBEIRO, Djamila. O que é lugar de fala?. Belo Horizonte(MG): Letramento, 2017.

RIBEIRO, Djamila. Quem tem medo do feminismo negro?. São Paulo: Companhia das letras, 2018.

Apresentação. In: AKOTIRENE, Carla. Interseccionalidade. Coleção Feminismos Plurais. São Paulo: Sueli Carneiro; Pólen, 2019, p. 13-15.

RUBERT, Rosane Aparecida. Comunidades Negras Rurais do RS: um levantamento socioantropológico preliminar. Instituto Interamericano de Cooperação para a Agricultura. Secretaria da Agricultura e abastecimento do Estado do Rio Grande do Sul/RS. Porto Alegre: 2005.

Religiosidades em Comunidades Quilombolas: algumas especulações. In.: DILlMANN, Mauro (Org.). Religiões e Religiosidades no Rio Grande do Sul. Vol. 4. São Paulo: Associação Nacional de História, 2016, p. 169-206.

ROSA, Graziela Rinaldi. Mulheres em movimento: perspectivas em educação, ativismo e empoderamento. Curitiba, PR: Nova Praxis editorial, 2019. 
SEIBEL, Ivan; FOERSTE, Erineu; ULLRICH, Henry Fred; JACOB, Jorge Küster; HEINEMANN, José Carlos. O povo Pomerano no Brasil. Santa Cruz do Sul: EDUNISC, 2016.

SOUZA, Bárbara Oliveira. Aquilombar-se: Reflexões sobre aspectos políticoorganizativos e identitários do Movimento Quilombola no Brasil. In.:SOUZA, Edileuza Penha de; NUNES, Georgina Helena Lima; MELO, Willivane Ferreira de. Memória, territorialidade e experiências de educação escolar quilombola. Pelotas: Ed. UFPel, 2016, p. 19-35.

SOUZA, Edileuza Penha de; NUNES, Georgina Helena Lima; MELO, Willivane Ferreira de. Memória, territorialidade e experiências de educação escolar quilombola. Pelotas: Ed. UFPel, 2016.

TIBURI, Marcia. Como conversar com um fascista. Reflexões sobre o cotidiano autoritário brasileiro. Rio de Janeiro: Record, 2016.

Recebido em setembro de 2019.

Aprovado em outubro de 2019. 